\title{
Research on Promoting the Society Affiliated to Hainan Association for Science and Technology to Undertake the Government's Transfer Functions with Institutional Innovation Against the Background of Free Trade Zone (Port) Construction
}

\author{
Xuan Gao \\ International Hospitality Management School \\ University of Sanya \\ Sanya, China 572022
}

\author{
Jing Geng \\ International Hospitality Management School \\ University of Sanya \\ Sanya, China 572022
}

\begin{abstract}
The Party Central Committee and the State Council regard the construction of the free trade zone (port) as a new policy designed to further reform and open up the national economy. Its purpose is to construct an internationally competitive business environment that conforms to international conventions, and make domestic enterprises internationally competitive in medical, education, tourism, finance, aviation, new energy and other fields. The previous experience reveals that the key to the success of free trade zone (port) construction is institutional innovation, moreover, which is bound to be accompanied by the innovation in the field of social management system. This provides a broad development space for social organizations, especially the Association for Science and Technology and its affiliated societies to undertake the government's transfer functions. Through the investigation of the current situation of Hainan Association for Science and Technology and its affiliated societies to undertake the government's transfer functions and taking the construction of free trade zone (port) as the background, this research looks for the new ideas and methods of Hainan Association for Science and Technology and its affiliated societies to undertake the government's transfer functions in the way of discussion in order to further improve the self-capacity of Hainan Association for Science and Technology and further improve the increasingly strong of the system of Association for Science and Technology to undertake the government's transfer functions.
\end{abstract}

Keywords-Hainan Association for Science and Technology; undertake the government's transfer functions; institutional innovation; free trade zone (port)

\section{INTRODUCTION}

In China, the free trade zone mainly refers to the special economic zone established within the national border but outside the customs duties with the purpose of free trade and trade facilitation, which is a kind of upgrading transformation of the existing tax-protected zone at that time, in order to better play the role of "window" opening to the outside world [1]. As of March 2017, the number of pilot free trade zone in China has increased from 1 in the past to 11 , which basically forms " $1+3+7$ " pattern of from the coast to the inland and east-west coordination [2].

In October 2017, at the 19th National Congress of the Communist Party of China, General Secretary Xi Jinping came up with to further delegate powers to the construction of the pilot free trade zone and explored the construction of the free trade port with greater reform autonomy [3]. After this concept was introduced, free trade port immediately became one of the hottest high-frequency words, which attracted wide attention at home and abroad. ${ }^{[4]}$ Soon afterwards, on the occasion of the 30th anniversary of Hainan Province became a special economic zone, the Party Central Committee declared that it would support Hainan Province to gradually develop the construction of the free trade port on the basis of the construction of the pilot free trade zone. [5] If the free trade port is version 2.0 of the free trade zone and is the performance of solidifying and deepening the reform and development [6], the essence of the state's support for the construction of the free trade zone (port) in Hainan is just like institutional innovation that has been repeatedly stressed by Liu Cigui, Secretary of the Hainan Provincial Party Committee [7]. Through the construction of the free trade port, breakthroughs and innovations in trade supervision, market access, financial opening and other aspects will be carried out, so as to form reproducible and propagable experience [8].

The construction experience of 11 domestic free trade zones shows that the process of promoting the construction of free trade zone must be accompanied by the reform and innovation in the field of administrative management system. Without the reform and innovation of the latter, the construction of the former is difficult to succeed [9]. Therefore, "taking back the hands of government and reducing government intervention" is the key point of the construction of free trade zone (port).[10] It is required to 
databases, which laid a good foundation for the association to undertake the government's transfer functions in the future. the relationship between government and market, and promote the construction of service-oriented government[11], which undoubtedly provides the broad development space for social organizations, especially the local Association for Science and Technology to undertake the government's transfer functions.

\section{THE CURRENT SITUATION AND EXPERIENCE OF HAINAN LOCAL ASSOCIATION FOR SCIENCE AND TECHNOLOGY TO UNDERTAKE THE GOVERNMENT'S TRANSFER FUNCTIONS}

Hainan Association for Science and Technology undertaking the work of the government's transfer functions as early as can be traced back to December $2000 .{ }^{12}$ At that time, Hainan Association for Science and Technology was entrusted by the department of Human Resources and Social Security of Hainan Province to undertake the review work of the professional titles of natural science researchers in the whole province. The peer recognition mechanism adopted in the review work has been affirmed by the Provincial Department of Human Resources and Social Security, which provides referential experience for other Science and Technology Associations at all levels and their affiliated societies in undertaking the government's transfer functions.

\section{A. The Basic Situation About Government Functions Undertaken by Hainan Association for Science and Technology and Its Affiliated Societies}

At present, data statistics display that Hainan Association for Science and Technology is more and more mature in undertaking the government's transfer functions. In 2017, a total of 29 societies undertook 75 items of government's transfer functions. The Provincial Quality Association undertaken 25 training missions of Provincial Tourism Committee, Provincial Quality Supervision Bureau and other government departments, with a total of nearly 4000 people trained. The Provincial Meteorological Society organized the capability evaluation test of the technicians of lightning protective device detection in 2017. The Provincial Mechanical Engineering Society held the "lift safety management and lift attendant operator training course". The Provincial Doctor Association and the organization department of Ding'an county Party committee of the Communist Party of China held the signing ceremony of talent strategic cooperation and carried out cooperation in education, health care, agriculture, tourism and other aspects. The Provincial Standardization Association undertakes the establishment of a series of local standards, such as the Standard for the Construction of Health Tourism and Service Trade Demonstration Base of Traditional Chinese Medicine in Hainan Province and the Standard for Service Trade of Traditional Chinese Medicine. The Provincial Immunology Society participated in the specially-appointed professor of national Yangtze River Scholar, national science and technology progress award, provincial science and technology project review, scientific research achievement evaluation and technology appraisal. The Provincial Preventive Medicine Association established four expert

\section{B. The Typical Cases of Government's Transfer Functions Undertaken by Hainan Association for Science and Technology and Its Affiliated Societies}

1) Hainan Quality Association is entrusted by the government to provide quality professional technical services and carry out the evaluation and training work of third-party customer satisfaction: Entrusted by the Quality and Technology Supervision Bureau of Hainan Province, Hainan Provincial Quality Association actively carried out the pilot activities for enterprises with standardized good behaviors, and cultivated 12 enterprises with standardized good behavior in 2017; organized four industries of wire and cable, Xingyue Bodhi, commodity concrete, and products related to food in our province to carry out the quality status survey of product production enterprises and form the Quality Analysis and Quality Improvement Plan Report of Wire and Cable Industry and other reports; undertook training course on improving quality management ability of new front-line employees in lowcarbon manufacturing industry, with a total of 600 participants.

2) The mid-term evaluation of Boao Lecheng international medical tourism pilot area project undertaken by Hainan Medical Association: On May 28, 2015, the Health and Family Planning Commission of Hainan Province issued the Measures for Medical Technology Evaluation of Hainan Boao Lecheng International Medical Tourism Pilot Area (Trial Implementation), entrusted the Provincial Medical Association to undertake the mid-term evaluation of Boao Lecheng international medical tourism pilot area project, and set the Secretariat of the medical technology expert committee of Boao Lecheng international medical tourism pilot area of the Health and Family Planning Commission of Hainan Province in the office of the Provincial Medical Association office. According to the requirements of the Evaluation Method, the Provincial Medical Association has recruited more than 260 national experts to form an evaluation team from 18 specialties recommended by the Chinese Medical Association, the China Medical and Health Promotion Association, the Shanghai Medical Association, the Zhejiang Medical Association, the Hunan Medical Association, the Hubei Medical Association, the Guangdong Medical Association and the Sichuan Medical Association on the platform of the association, and signed the evaluation agreement with Boao international medical tourism pilot zone management committee to clarify the rights and obligations of both parties. Up to the present, the Provincial Medical Association has received 90 evaluation projects handed over by the management committee, which is divided into 14 batches, and carried out evaluation on 53 projects. 
attendant operator training course" project of the Quality and Technology Supervision Bureau of Hainan Province, and the Provincial Association for Science and Technology actively communicated with the Quality and Technology Supervision Bureau of Hainan Province to ensure the smooth implementation of the training project.

For the functions that the government is preparing to transfer, Hainan Association for Science and Technology shall organize relevant societies to study in-depth, carefully research the deployment and key points of the current government's transfer functions in Hainan Province, make clear the government functions that can be transferred and the functions that they can undertake, and make sure to find the breakthrough and docking point. Since 2016, Hainan Association for Science and Technology has focused on several provincial associations with strong professional affiliation with government departments, such as the Provincial Meteorological Society and the Provincial Society of Surveying and Mapping Geographic Information, in order to try to promote the establishment of science and technology awards. At present, Hainan Meteorological Society has successfully undertaken the award review project of scientific and technological papers and excellent scientific and technological workers of Hainan Meteorological Bureau, and Hainan Surveying and Mapping Geographic Society has also undertaken the award review work of excellent papers and excellent engineering projects of Hainan Surveying and Mapping Bureau.

3) To strengthen the self-construction of the society and lay a solid foundation for undertaking the government's transfer functions: The process of undertaking the government's transfer functions is also the process of strengthening the self-construction of the society. On the basis of strengthening the influence, cohesion, credibility and independent development ability of the society, the society affiliated to Hainan Association for Science and Technology takes the initiative to do a good job in selfconstruction, improve the operation and management of organization, gradually promote the specialization of the secretary general and the substantiation of the secretariat, enhance the authority and social recognition in its own field, so as to provide organizational guarantee for undertaking the government's transfer functions.

At the same time, Hainan Association for Science and Technology actively carries out the review work of star society, guides the provincial society meeting the requirements to participate in the review in the way of project application, gives financial support to the society with a star rating, and commits to building the society into a brand science and technology society with good social reputation, strong development ability, high academic level, remarkable service effect and standardized internal management. From October 2016 to June 2018, Hainan Association for Science and Technology has awarded 18 star-rated societies ("Table I") and allocated 1.24 million yuan of project funds.
For example, in June 2017, Hainan mechanical engineering society undertook the "lift safety management and lift 
TABLE I. STAR-RATED SOCIETIES OF HAINAN ASSOCIATION FOR SCIENCE AND TECHNOLOGY IN 2018

\begin{tabular}{|l|l|l|}
\hline S/N & \multicolumn{1}{|c|}{ Society declared } & Star awarded \\
\hline 1 & $\begin{array}{l}\text { Management Modernization } \\
\text { Research Association }\end{array}$ & Four-star \\
\hline 2 & Nursing Society & Four-star \\
\hline 3 & Botanical Society & Four-star \\
\hline 4 & Civil construction Society & Three-star \\
\hline 5 & Electronics Society & Three-star \\
\hline 6 & Intellectual Property Association & Three-star \\
\hline 7 & Stomatology Society & Three-star \\
\hline
\end{tabular}

III. OPPORTUNITIES FOR HAINAN ASSOCIATION OF SCIENCE AND TECHNOLOGY AND ITS AFFILIATED SOCIETIES TO UNDERTAKE GOVERNMENT'S TRANSFER FUNCTIONS IN THE CONSTRUCTION OF FREE TRADE ZONE (PORT)

According to the experience of free trade zones in Shanghai, Guangdong and other places in the past, from the perspective of development and expansion, free trade zones shall encourage all sectors of society to actively participate in the construction of free trade zones in order to stimulate social vitality. At the same time, for matters not prohibited by laws and regulations, social organizations shall also be encouraged to actively carry out reform and innovation activities in the pilot free trade zone ${ }^{13}$ so as to achieve the goal of fully stimulating the vitality of market subjects. Therefore, in the process of building a free trade zone (port), Hainan Provincial Government and local governments at all levels need to clear up which responsibilities can be transferred to social organizations by transferring functions, especially Hainan Association of Science and Technology and affiliated societies. Specifically:

\section{A. Hainan Association of Science and Technology and Its Affiliated Societies Can Participate in Industry Supervision}

Hainan Provincial Government and local governments at all levels can carry out innovation in the way of administrative management, pay attention to process supervision, and promote the supervision system that combines administrative supervision, industry self-discipline and social supervision. Therefore, in the construction of the free trade zone, for example, Hainan Tea Association, Hainan Bee Industry Association, Hainan Orchid Association, Hainan Cooking Association, Hainan Tobacco Association, Hainan Jewelry and Jade Association, Hainan South Subtropical Flavor Promotion Association, etc., can undertake the relevant industry regulatory government functions transferred from the government, carry out industry supervision and provide more professional services, so as to achieve the goals of saving administrative expenses and improving administrative efficiency.

\section{B. Hainan Association of Science and Technology and Its Affiliated Societies Can Provide Industry Consulting Services}

One of the key points to build the free trade zone is that professional institutions shall undertake the matters they are suitable for, or introduce competition mechanism to cultivate the development of professional institutions by purchasing services and other ways. Taking Hainan Low Carbon Economic Development Promotion Association as an example, during the construction of the free trade zone, the opportunities faced by the Association include: providing consulting services for investors; carrying out talent exchange, business investigation, material circulation and enterprise personnel training; and helping domestic and foreign enterprises who want to carry out business in Hainan to carry out liaison and project investment, etc. Similar Associations for Science and Technology, such as Hainan Electrical Engineering Society, Hainan Mechanical Engineering Society, Hainan Computer Society, Hainan Electronic Society, can help companies in the free trade zone (port) to develop human resources, establish trade information sharing platform, and carry out business training and other professional services.

In addition, the construction of the free trade zone also includes environmental protection. In this regard, Hainan Ecological Society, Hainan Plant Protection Society, Hainan Wildlife Protection Association, Hainan Plant Society and so on in most cases have professional teams and experts, rich practical experience, quick response ability and other characteristics, which is also conducive to absorbing advanced international experience to contribute to the environmental protection work of the free trade zone.

\section{Hainan Association of Science and Technology and Its Affiliated Societies Can Participate in the Legal System Construction}

The construction of Hainan free trade zone (port) needs to adjust some local laws and regulations, especially those that are not suitable, adaptive or conducive to the development of the free trade zone, shall be submitted to the people's Congress of Hainan Province and the people's Government of Hainan Province to make provisions on its applicability in the construction of the free trade zone (port). Due to the particularity of the free trade zone (port), the legal environment of the free trade zone (port) is special. Therefore, it is necessary to participate in the construction of the laws and regulations of the free trade zone (port) with the help of social forces, especially the professional institutions and associations related to the law. The legal system with the characteristics of Hainan free trade zone (port) shall be "tailor made" in a reasonable and stable manner and can be promoted to the whole country.

In terms of intellectual property protection, such as Hainan Science and Technology Enterprise Federation, Hainan Standardization Association, Hainan Intellectual Property Association, Hainan Tropical Crops Association, etc., can participate in collaborative management and law enforcement cooperation, and explore the establishment of a unified management and law enforcement system and mechanism of intellectual property in the free trade zone. In terms of the administrative reconsideration system, the specific administrative actions of the free trade zone may cause the dissatisfaction of the administrative counterpart. Therefore, Hainan City Finance Society, Hainan Ecological Society, Hainan Chemical Engineering Society, Hainan 
Forensic Medicine Society, Hainan Stomatology Society, Hainan Tropical Medicine Research Society, etc. can participate in the establishment of a complete set of administrative reconsideration system or accept the entrustment to carry out administrative reconsideration. In terms of relations between labour and capital, free trade zone can implement collective negotiation mechanism and labor dispute settlement mechanism between enterprises and workers. When the labor consultation and labor dispute involve scientific and technological workers, Hainan Association for Science and Technology and its affiliated societies, such as Hainan Doctoral Association, can participate in.

\section{Suggestions For Hainan Association OF SCIENCE AND TECHNOLOGY AND ITS AFFILIATED SOCIETIES TO \\ UNDERTAKE THE GOVERNMENT'S TRANSFER FUNCTIONS IN PROMOTING THE CONSTRUCTION OF FREE TRADE ZONE} (PORT)

\section{A. To Raise Awareness and Actively Change Ideas}

In order to ensure that Hainan Association for Science and Technology and its affiliated societies undertake the government's transfer functions in an orderly manner, the relevant government departments at all levels and Association of Science and Technology and its affiliated societies must practically emancipate their minds and raise their awareness. Government departments at all levels shall face up to and attach importance to the role of Association of Science and Technology and societies, abandon the thinking mode of "interests first", and really transfer the functions that should have been transferred to Hainan Association of Science and Technology and its affiliated societies, rather than transfer them to their subordinate institutions, or still take on all things. At the same time, Hainan Association of Science and Technology and its affiliated societies shall have the awareness of unexpected development, overcome the thought of "relying on others", and take the initiative by relying on their own academic, talent and extensive contact advantages. They shall not only attach importance to the functions transferred from the government departments, but also develop new social functions according to the market demand, and gradually make it big and obtain social recognition.

\section{B. To Take the Initiative to Undertake and Enhance the Vitality of the Society}

It is a long-term and complex process to undertake the work of government's transfer functions, which requires Hainan Association of Science and Technology and its affiliated societies to constantly improve their service ability and management level, and actively strive for it. If they just wait passively, do not take the initiative and do not make great efforts to improve their own ability and level, the development of society will go into a dead end, and be far away from the sustainable, stable and healthy development path, and it is impossible to undertake the government's transfer functions. Therefore, Hainan Association of Science and Technology and its affiliated societies must strengthen their ability to adapt to the external over-all environment and fully remove all positive factors to serve their own development.

\section{To Carry out Scientific Management and Enhance Capacity Building of the Society}

In order to perform the responsible functions, Hainan Association for Science and Technology and its affiliated societies shall not only give full play to the advantages of the society, but also strengthen the management of the society and make a good job of its own construction, especially promote the specialization of the secretary general and the substantiation of the secretariat. Under the background of Hainan free trade zone (port) construction, Hainan Association for Science and Technology and its affiliated societies shall seize the opportunity of institutional reform and functional transformation of Hainan Provincial Government, rise to the challenges, do a solid work, and promote the continuous improvement of the capacity of Hainan Association for Science and Technology and its affiliated societies.

\section{CONCLUSION}

Promoting the reform of social public service is an important link in the construction of Hainan free trade zone (port). Under this goal, Hainan Provincial Government needs to carry out the supply side reform of public service as soon as possible, and transfers some public service functions that can be transferred. As an important bridge and link for the Party and the government to contact scientific and technical workers, Hainan Association for Science and Technology and its affiliated societies are actively promoting the undertaking of government's transfer functions. And on the basis of learning from domestic and foreign experience, they are gradually carrying out the reform according to local conditions, and have made remarkable achievements and experience. The practice indicates that the key to undertake the government's transfer functions for Hainan Association for Science and Technology and its affiliated societies is that the government functions shall be "transferred", the Association for Science and Technology shall be able to "accept", and the transfer functions shall be "well used". Therefore, Hainan Association for Science and Technology and its affiliated societies shall seize the opportunity of the construction of free trade zone (port), research the current situation and policies carefully, and have a thorough grasp of the long-term plan of the Party Central Committee for the future development of Hainan. It shall promote Hainan Association for Science and Technology and its affiliated societies to well undertake the government's transfer functions, perfect the social governance mechanism and system innovation, and provides strong support for promoting the construction of Hainan free trade zone (port) by means of "improving the understanding and actively changing the concept", "taking the initiative to enhance the vitality of the association", and "carrying out scientific management to strengthen the capacity-building of the society 


\section{REFERENCES}

[1] Qiang Jianxin. Shanghai Pilot Free Trade Zone - Assist the "Upgrading" of China's Economy [J]. World Knowledge, 2013 (18): 52-54 (in Chinese)

[2] Xu Jing, Wang Xieyong. China's Pilot Free Trade Zone: Research Review, Development Status and Prospect [J]. Journal of Dalian University, 2018,39 (01): 124-131 (in Chinese)

[3] Zhou Guirong, Li Xiaohui. Experience in the Construction of Foreign Free Trade Port and Its Enlightenment on the Institutional Innovation of Tianjin Free Trade Zone [J]. Tianjin Economy, 2019 (02): 3-8 (in Chinese)

[4] Huang Maoxing. Benchmarking and Integrated Development of Free Trade Zone and Free Trade Port $[\mathrm{N}]$. Hainan Daily, November 7, 2018 (A07) (in Chinese)

[5] Chi Fulin. Hainan: Opening Mode Is More Important Than Preferential Policies [N]. Economic Information Daily, May 8, 2018 (001) (in Chinese)

[6] Xiong Hou, Sun Nanxiang. New Pattern of Full Opening of Free Trade Port Pathfinding [N]. Taiyuan Daily, December 7, 2017 (007) (in Chinese)

[7] Zhong Yu. Planning with High Starting Point, Construction with High Quality, Move to New Heights in Reform and Opening Up in the New Era - An Exclusive Interview with the Office of the Working Committee of the Pilot Free Trade Zone (Free Trade Port) of the Hainan Provincial Party Committee [J]. Today's Hainan, 2019 (01): 10-12 (in Chinese)

[8] Lu Hua, Shanghai Free Trade Zone Comprehensive Research Institute, Fudan University. Stimulating Endogenous Power of Free Trade Port Construction in Hainan Free Trade Zone by Continuous System Innovation [N]. Hainan Daily, March 13, 2019 (009) (in Chinese)

[9] Guo Gaojing, Meng Wei. Research on the Attention Allocation of the Transformation of Government Functions in China (Shanghai) Pilot Free Trade Zone: Based on Weighted Co-word Analysis of 83 Policy Texts [J]. Information Journal, 2018,37 (02): 63-68 (in Chinese)

[10] Tang Delong, Yang Jun, Gao Xiang. The Construction of Free Trade Zone and Social Organizations Undertake the Functions Transferred by the Government [J]. Modern Economic Discussion, 2015 (03): 3337 (in Chinese)

[11] Wang Zhipeng. Reflections on Transferring Government Functions and Building Service-Oriented Government [J]. Institutions and Administration, 2017 (07): 8-10 (in Chinese)

[12] Hainan Association for Science and Technology. Improving the Ability of the Society to Undertake Government Functions [J]. Society, 2015 (10): 31-32 (in Chinese)

[13] Seven Highlights of the Regulations Focus on Reform and Innovation [N]. Shenzhen Special Economic Zone Daily, 2016-08-16 (A05) (in Chinese) 